\title{
THE ROLE OF THE OTTOMAN-TRAINED OFFICERS IN INDEPENDENT IRAQ
}

\section{YÜCEL GÜÇLÜ}

The need for a stable supply of officers stationed in the Arab provinces prompted the Sublime Portc in 1871 to invite Iraqis to choose the military as a profession:

Due to the fact that Baghdad, our city, is the headquarters of the Imperial $6^{\text {th }}$ Army of the Iragi districts, the establishment of a military sccondary school there is very necessary. Students who complete their studies in this school will be sent to the Imperial War College in lstanbul to continue their cducation, so that they might grauate as officers. The school opens a clear future to its graduates up to the rank of field marshal and it is indispensable for the progress of our countrymen. ${ }^{1}$

The military sccondary school was cstablished in Baghdad in 1872. Altendance in 1898 was 269 students; in 1900 it was 256. By 1909 another military sccondary school had becn opened in Sülcymaniyc. The government paid the students' expenses in Baghdad, including room and board and sent the graduates of the military sccondary school to Istanbul, reimbursing their traavel fecs and supporting them through the War College. Thus the army became an idcal carcer for lower-class Iraqis from less prominent families. Poor farmilics made their sons attend the military secondary school in Baghdad so that it might lead to their completing their higher studies in the

\footnotetext{
${ }^{1}$ A. W. A. al-Qaysi, The Impact of Modernisation on Iraqi Society During the Ottoman Era: A Study of Intellectual Development in Iraq, 1869-1917, Ph.D. Diss., University of Michigan, Ann Arbor, 1958, pp. 85-86.
} 
War College in İstanbul and graduate as officers in the Ottoman army. For them, military education became a popular means for social mobility. ${ }^{2}$

Each ycar from 1874 to the First World War, an average of thirty to forty Iraqi military sccondary school graduates went on to İstanbul; in 1903 the Iraqis were ten percent of the total number admitted to the War College. By 1914, the military secondary schools in Iraq were sending over a hundred cadcts a ycar to İstanbul. By the beginning of the First World War some 1,200 had become Otoman army officers. Graduates of the War College in Istanbul were commissioned as licutenants and most of the Iraqis among them were later stationed in their provinces. By imperial decrec, officers from Arabic-spcaking areas were sent back to their own regions, while other officers drew lots for assignment. From the last quarter of the ninctecnth century up to the end of the First World War, no Arab district supplied more, or of higher standard, officers to the Ottoman army than did Iraq. ${ }^{3}$

Iraqis studying at the Istanbul War College were comfortable in the Ottoman milicu. As Iraqi Moslems under Ottoman suzcrainty for more than 300 ycars, they had become acclimatised, accepting the spiritual and temporal leadership of the Ottoman sultan-caliph, looking to Iraqis such as Mahmut Scrket Pasha, who had attaincd a high position in the Ottoman establishment, as an ideal example of upward mobility. They appreciated the opportunity to study in cosmopolitan Istanbul, the center of intellectual ferment. While at the War College, they learned French and attended lectures by Gcrman instructors on the history of war, wcapons, military organisation, strategy, tactics and military litcrature. As army cadets, they were impressed with the technical and military education they received, by the general staff system that instilled order and respect for efficiency, and with the clevation of the methods of war to the Icvel of science, once again creating the possibility of Moslem military ascendance. Reading the chicf German instructor General Colmar Freiherr Von Der Goltz's The Nation in Arms, they were impressed by his thoughts on the rolc of the army and education in socicty. But they read other things as well. Like the Turks, the Arab students secretly

${ }^{2}$ A. R. al-Hilali, History of Education in Iraq in the Ottoman Era: 1538-1917, Baghdad, 1959. pp. 164 and 220. Sec also K. Karpat, 'Reinterpreting Ottoman History: A Note on the Condition of Education in 1874', International Journal of Turkish Studies, Vol. 2, 1981 1982, pp. 93-100 and D. Pool, 'From Elite to Class: The Transformation of Iraqi Leadership, 1920-1939', International Journal of Middle East Studies, Vol. 12, 1980, pp. 333-335.

${ }^{3}$ Ibid. M. Griffiths, The Reorganisation of the Ottoman Army under Abdulhamid II, 1880-1897. Ph.D. Diss., University of California, Los Angcles, 1966, p. 177. Also S. Longrigg, Iraq 19001950: A Political, Social and Economic History, London, 1953, p. 38. 
read the works of Namik Kemal, the Ottoman liberal, and they joined the Arab-Ottoman brotherhood socictics which advocated cquality for all members of the Ottoman Empirc. ${ }^{4}$

The Arabs were brethren in faith with the Turks but had a number of grievances against the Ottoman administration. In Iraq, the poets Maruf alRusafi (1875-1945) and Jamil al-Zahawi (1863-1936) criticised absolute rule's injustices while remaining loyal Otsoman subjects. When the Young Turk revolt occurred, therefore, Irapis saw the new regime as one of reform. In fact, the Young Turks, following their revolution, made a gesture of good will towards the Arabs. The policy of Ottomanism was adopted with a view of assuring common lotaly to the Empire on the basis of cquality. But this only proved to be a bricf interlude and was followed by disappointment. Growing efforts to link the provinces more tightly to Istanbul and the call to firmer discipline were the Young Turks' formula for regencrating the Ottoman Empirc. Arab intelligentsia resented the Young Turks' policy of centralisation. The Arabs did not conceal their bitterness and the rupture was a signal for them to organise nationalist associations. Arab intellectuals and political activists began to come around to the vicw that the cultural and political aspirations of the Arabs would be better served by the separation of the Arab provinces from the rest of the Ottoman Empire and, some felt, by the creation of an Arab statc under an Arab king. A few of these individuals were also aware that the achicvements of these aims would not be entircly unwelcome to the European powers, particularly Britain. 5

As a result, number of Arab sccret socictics were established in various parts of the Empire. One of these, al-Ahd (the Covenant), founded by Aziz Ali al-Misri in 1914, was dominated by a group of army officers of Iraqi origin, many of whom were to become leading politicians under the mandate and monarchy. Hence by the time of the First World War the idea that the Arabs should break away from the Ottoman Empire, though generally not the more specific notion of forming a sepcrate Iraqi state, had begun to gain ground among political activists in Iraq and some of these Iraqi officers were to play a major role in the British-sponsored Sharifian army, which started the Arab revolt in the Hijaz in 1916. An unspecified number of officers of Iraqi origin in the Ottoman army, such as Nuri al-Said, offered their services

\footnotetext{
4 Ibid.

${ }^{5}$ See H. Kayal, Arabs and Young Turks, London, 1997, in particular chapter three on "The Opposition and the Arabs, 1910-1911', pp. 81-115. Also G. Lencrowski, The Middle East in World Affairs, New York, 1958, pp. 45-46 and 94 and S. Shaw and E. K. Shaw, History of the Ottoman Empire and Modern Turkey, New York, 1977, Vol. 2, pp. $273-280$.
} 
to the British and many of them eventually entered the so-called North Arab Army to scrve cither on Faisal's staff or as field commander. ${ }^{6}$

It must, however, be particularly pointed out that most Arab officers remained loyal to the Ottoman statc to the end of the war. Among those who joined the Sharifian army were very few who on their own initiative had gone over to the Ottoman Empirc's enemics. The British recruited Faisal's soldiers from the prisoncr-of-war camps in India, requesting that the India command send the Arab prisoncrs to the Hijaz, which they began to do in 1916. Many Iraqis were not informed of their destination, nor were they given advance bricfing, so that of the 132 prisoners who arrived in Junc 1916, for example, 102 officers and soldiers refused to fight the Turks; of the eleven officers, only threc joined the Sharifians. ${ }^{7}$

King Faisal I of Iraq received his crown from the British and derived his support from British planes and, primarily, from the clique of Ottomantrained army officers who had shared a common background of school, military scrvice and experience of Faisal's provisional government in Syria. These officiers, most of whom entered the new Iraqi officer corps or took up civilian posts after the creation of the Kingdom of Iraq comprised the new state's cducated clitc. Both the Ottoman Empirc with its focus on Islam and the Arab provinces as thcy had known them, no longer existed. Sccularly educated, the officers drew upon their İstanbul educational experience and subsequent war-time events in order to devise their own idcology. Like Faisal, they had little support in Iraq although most of them had been born there. Altogether their number amounted to about 300 and, with few exceptions, they were of Sunni sect and came from Baghdad or the northern part of the country. The only conncctions which Faisal had with Iraq were through these officers and their roots were not decp. Few came from notable or leading families. The strength of the bond tying them to the throne differed according to individual circumstances, but it is uscful to distinguish between the later recruits to the Sharifian causc, i.c. the officers who joincd Faisal's scrvice in Syria after the end of the war with the Turks in October 1918, like Yashin al-Hashimi who did not desert the Ottoman army but rose to the rank of a gencral and gained successes against the British troops in Palcstine, and the earlier voluntecrs who rallied from the beginning to the revolt raised in 1916 by Faisal's father, Sharif Hussain of Mecca, or took an active part in

${ }^{6} \mathrm{M}$. Farouk-Sluglett and P. Sluglett, Iraq since 1958: From Revolution to Dictatorship, London, 1987, p. 7.

${ }^{7}$ B. C. Busch, Britain, India and the Arabs: 1914-1924, Los Angeles, 1971 , p. 175. 
the ensuing desert campaigns and, of necessity, became more closely identificd with the Sharifian family and its interests. ${ }^{8}$

Of course, Faisal relicd, in the first place, on the officers who fought for him longest or stood by his side through danger or adversity, on such men as, Jafar al-Askari, Nuri al-Said, Jamil al-Midfai and Ali Jawdat alAyyubi, all of whom rose eventually to the premiership. Attachment to the Sharifian cause and to Faisal's movement in Syria gave them an advantage. These men had no personal wealth or family prestige and hence were dependent upon Faisal for their power. Typical of this group was Nuri alSaid, born in Baghdad in 1888 of a family with a modest position in the Ottoman burcaucracy. Educated at the Baghdad military secondary school and later at the War College in Istanbul, he was the only Ottoman army officer or Iraqi origin to desert the armed forces before the outbreak of the First World War. Later he worked with the British and Faisal. Nuri al-Said returned from Syria to become the Chicf of Staff of the newly formed Iraqi army in 1921. He became Deputy Commender-in-Chief of the army in 1924, Defence and Forcign Minister in 1927 and in 1930 Prime Minister for the first of thirteen times. Nuri al-Said's carly education, military training and army service under the Ottoman Empire set his character and determined his course as a public figure. ${ }^{9}$

The crcation of a national army was stimulated by the necessity of absorbing, as far as possible, the large and articulate group of unemployed and discontented ex-officers from the Ottoman army. The problem was further aggravated by the acute jealousy between the cx-Sharifian and ex-Ottoman officers. Morcover, Iraqi cx-olficials formerly in Ottoman service (and some of them, indecd, did not desert the Turks until the fall of the Ottoman Empirc) as well as local notables regarded the ex-Sharifian officers with suspicion and fear, lest they appropriatc all the best posts. There was, for that matter, definite animosity between the Sharifian veterans and former officers from the Ottoman service such as Bakr Sidqi who staged the 1936 coup. ${ }^{10}$

The Sharifian officers who Faisal brought with him were, of course, too few to govern the country on their own. As is indicated above, they had to share power with the ex-Ottoman officials, who had neither taken part in the Sharif's rebellion nor had desired secession from the Ottoman state. For these of ficials, who had themselves formed part of the state, the condition of

\footnotetext{
${ }^{8}$ H. Batatu, The Old Social Classes and the Revolutionary Movements of Iraq, New Jersey, 1978, p. 319.

${ }^{9}$ W. Gallman, Iraq Under General Nuri, Baltimore, 1964, p. 88.

${ }^{10} \mathrm{P}$. Ireland, Iraq: A Study in Political Development, London, 1937. p. 224.
} 
Iraq after 1918 was most unsatisfactory. Once they had helped to rulc a state which was the one Moslem Great Power in the world, now they were confined to a pelty kingdom which was occupicd and controlled by a Christian power. This power had, furthermore, brought in a number of obscure men and put them in positions of authority; and these men were claiming that they were the only genuine Arab nationalists, that their uprising had inaugurated a new Arab renaissance, when in fact they had mercly becn accessorics to the humiliation of Islam. The sardonic bitterness of these official classes, without whom lraq could not be governed, knew no bounds. The clicnts of the British, Arab nationalists? They would show them who were the true nationalists. When Nuri al-Said negotiated a treaty with Britain in 1931, his opponents sct up a great agitation, claiming that the treaty did not give Iraq true independence but was merely a diabolic device to subject the country more firmly than ever to British control. In the controversics which ensucd, the supporters of Nuri al-Said and Jafar al-Askari taunted Yasin al-Hashimi, who was opposed to the treaty, with having done nothing for Arab nationalism: he had not abandoned the Ottomans in mid-war as the Sharifian officers had done, but had fought by their side until the end. 11

Onc of al-Hashimi's followers, Fahmi al-Mudarris, was moved to reply. 'It is not wisc', he wrote, to blame al-Hashimi for having stood firm with the Ottoman army until the last shot had becn fircd. His behaviour can be justificd on two counts. In the first place, he had the duty, as a faithful commander, to preserve the army and his own honour; in the second, he believed that the destruction of the Ottoman army would lead the Arabs to be delivered over and to submit to the Allies who would divide up their country into zones of influence, which is in fact what happened. Secing what it means to kcep faith, and what military regulations arc, had al-Hashimi abandoned the Ottomans he would have included himself in the category of traitors. Again, how dare Faisal and his family claim to be the leaders of the Arabs and to have saved them from Ottoman rulc? In Ottoman times people were not used to hear of titles such as King of the Hijaz. - a title which Faisal's father had taken to himself. On the contrary, the proudest title of the Ottoman sultan-caliph on the ruins of whose empire Iraq and so many other countrics were built, cxclaimed al-Mudarris, was that of Khadim al-haramian al-sharafain (the Scrvant of the Two Holy Places of Mecca and Medina); the highest rank in which the sultan-caliph glorified was that of Swecpers of the Holy Places; did they not use the broom as a symbol of their rule? ${ }^{12}$

\footnotetext{
${ }^{11}$ E. Kedouric, The Kingdom Iraq: A Retrospect, in The Chatham House Version and other Middle Eastern Studies, London, 1984, pp. 276-277.

12 Ibid., pp. $277-278$.
} 
Al-Mudarris expressed to perfection an attitude which was encountered again among the official classes of Irag whose Ouman carecrs had been ended by the British occupation: Iraq, he wrote, never was a Turkish colony; it was part of the Ottoman Empire which had been independent for more than six centurics. Neither was the state Turkish, but Ottoman. This meant that it gathered under its banner different races in the same manner as the Iraqi state would today, had it been independent. The Iragis were not under the yoke of Turkish rulc, as they are today under the Turks and the other races, in all the department of the statc. There was no discrimination in rights or dutics between the Turks and the Irayis, and they shared offices, high positions and the good and the bad equally. The Iraqi excreised rulc, justice, administration and politics for centuries, not only in Iraq, but in all parts of the Ottoman Empirc, which extended to Europe, Asia and Africa. ${ }^{13}$

The German military advisers who reinstituted the Ottoman system of military cducation from 1880 s onwards envisioned an officers corps trained and organised on the Prussian model, namcly an elite, homogencous, unificd group, albcit in this casc drawn from the various linguistic and social groupings that made up the Empirc. It would cxist as a distinct social class and be the heart and soul of the army. The unity of its membership would not necessarily be through direct loyalty to the monarch but rather through the sharing of common experience and profession. Having common interests and common dutics, the whole body would render itself responsible to each individual member. Thus, Iraqis who passed through the Ottoman military system maintained a bond even though they fought on different sides during the First World War. Yashin al-Hashimi, for cxample, who had scrved with Ottomans and was wounded in the fighting in Palestinc, was rescued by Nuri al-Said, who was fighting with the British, not only because the former was an Iraqi but because they were comrades-in-arms from the War College. Later, in Iraq, they were political adversarics during most of their carcers, working together only when politics required their cooperation. ${ }^{14}$

The legacy of the Ottoman military cducation transcended purely military matters. It led to a system of networking and politicisation that would play a large role in Iraqi and Arab politics in later years. By the end of 1920s, the Ottoman-traincd officers became the governing class in Iraq and until a new gencration of military men extinguished their flame in 1958 , they played a dominant role in public affairs through their possession of a wide array of political positions such as ministcrial offices ambassadorships, provincial governorships, court officials and army officers. Nine of the fourtecn prime ministers from 1921 to 1932, for example, were former Ottoman army officers as werc thirty-two out of fifty-six major cabinet

13 Ibid., p. 278.

14 Pool, From Elite to Class, pp. 333-337. 
members. By 1936, among the Iraqi officers holding posts of commander and above in the new army, fifty out of sixty-one were cx-Ottoman olficers who had reccived their cducation in Istanbul. ${ }^{15}$

There was also a direct link between the politicised officers who controlled the Iraqi government after 1936 and the Ottoman military system. Two teachers in the Iraqi Military Academy, in particular, propagated the active role of the army in politics. The first, Tawfik Hussain, a product of the Ottoman military systcm, remained in the Turkish army until his return to Iraq in the carly 1930s. Appointed instructor in military history by Taha al-Hashimi, who kncw him from İstanbul, Hussain lectured extensively on nationalism. He influenced the post-1930 gencration of Iraqi officers by advocating that Iraq should be like Turkey. His hero was Kemal Atatürk and his lectures inspired many officers to envision themselves in the role of the Turkish leader. By 1934, Hussain had more than scventy officers in his circle, including the lcader of the 1941 coup in Iraq, Salah ud-Din asSabbagh. The second tcacher was Taha al-Hashimi, a graduate of the Baghdad military secondary school, who attended the Istanbul War College and Staff Academy. Although al-Hashimi scrved in the Otoman Army, where he reached the rank of licutenant colonel, he was better known as a teacher because of his predilcction for military studics, history and geography. Most of his carcer in Iraq was as Commander-in-Chief of the Army, where he was eventually promoted to general. Al-Hashimi also tought in the Military Academy and wrote textbooks. ${ }^{16}$

There is evidence that attendance at the Baghdad military secondary school and Istanbul War College was most influential expperience for many army officers who later achicved political power in Iraq. To be sure, other facts such as a social bakground, family and religion played a large role in forming a person's later political world vicw. Nonetheless, the shared schooling and experiences, and the friendships many of these officers made during this period of carly adulthood, lasted and, for many of them, determined the circle of persons with whom they staycd in contact throughout the remainder of their lives.

The carly 1920s, which brought the creation of the Iraqi state, also marked the beginning of stiff opposition to forcign control. From the very foundation of the Iraqi kingdom, there was the nagging fecling that it was a make-believe kingdom, built on false pretences and kept going by a British design and for a British purpose. This was the origin and explanation of the rabid anti-British feclings of large sections of the ruling classes of Iraq, a

\footnotetext{
15 Ibid. Sce also P. Marr, 'Iraq's Leadership Dilemma: A Study in Leadership Trends, 1948-1968', Middle East Journal, Vol. 24, 1970, pp. 297-298. 16 Ibid.
} 
fecling which persistcd until the end and which occasionally exploded in bursts of hatred and outragc. The British indecd had few friends in the kingdom they founded. The King and the Sharifian officers who came with him did not dare show gratitude to their patrons, but must always be pressing them for further concessions to make secure their own position and prestige. Moreover, the institutions of the mandate were calculated to arouse suspicion in the minds of the Moslem politicians and administrators. Their blunt, uncomplicated minds saw in politics nothing but the excrcise of power, and when they found themselves flanked by British advisers who were susposed to guide their steps and instruct them in Leaguc of Nations virtues, they were convinced that this was but an underhand manner of undermining their authority and diminishing their power. They were also indignant that Christians and forcigners should presume to teach them, who had ruled the country in Ottoman timcs, how to govem. ${ }^{17}$

Nationalist opposition was to dominate the political scene right up to the revolution of 1958. The single minded struggle against the mandatory power, often aceentuated violence and insurrection, finally achieved nominal independence in 1932. The conflict with Britain distracted the leadership from the pressing domestic problems and stood in the way of cooperation with the West that might have been bencficial to Iraq. The end of the mandate had significance for the ex-Sharifian officers gathered around King Faisal, in giving them a freer hand to excrcise control within the country, but the British authorities retained supreme power and the vast majority of the population continued to be cxcluded from any meaningful participation in government. ${ }^{18}$

The throne inherited most of the power left by the British and cabinets continued to be controlled by pro-British former Ottoman army officers led by Nuri al-Said. The tightening grip of Faisal and his pro-British cohorts, in return, spawned a new opposition, which atlacked the new treaty of 1930 and the British connection. This movement was far morc broadly based and ably led than the opposition movements of the 1920s. Like the members of the government, the opposition leaders were mainly Ottoman-trained army officers, but because of their opposition to the British and the treaty they had remained at the margins of power. ${ }^{19}$

The next twenty-six years of what was now the independent state represent, to a very great extent, a continuation of the mandate in the sense

\footnotetext{
${ }^{17}$ Kedouric, The Kingdom Iraq, pp. 278-279.

${ }^{18}$ P. Mansficld, The Arabs, London, 1982, pp. 233-234.

${ }^{19}$ Foreign Office Papers, Public Record Office, London - henceforth referred to as 'F.O.' - 371/800/392. Ogillivie-Forbes (Baghdad) to Seymour, 3 September 1934.
} 
that the 'permitted political arena' continucd to be occupicd by the same old groups of people who had bccome prominent in the 1920s and their close friends and associates. Politicians in Baghdad continued to jockey for position, ignoring real problems. As cabincts succeded one another, the fabric of state and the constitutional structure began to crode. The most obvious difference between the politics of the 1920s and those of the 1930s, particularly after the death of King Faisal $I$ in 1933 and the succession to the thronc of his son Ghazi (1933-1939), was the cmergence of the armed forces as a new locus of political power, although in many ways this devclopment was more a change of style than of substance. ${ }^{20}$

Here one has to remark that the carricrs of aspirations to Arab nationalism and the content of the aspirations themselves underwent important qualitative changes with the passage of lime. In the case of the Sharifian officers who threw in their lot with Faisal and the Irayi state after 1921, their original patriotic and nationalist attitudes are not in doubt. By the end of the 1920s, however, it was clear that such figures as Nuri al-Said and Jafar al-Askari had become content to accommodate themselves to the British, with the result that any Arab nationalist credentials they might once have had gradually ccased to count in their favour among the Iraqi population.

Simultaneously, considerable ferment could be noticed in the armed forces. A group of officers belicved that the army was the only organised authority capable of accomplishing the desired change and initiating the neccessary reforms. The army had cstablished its patriotic and nationalist credentials in the hearts of many members of the urban population in the summer of 1933 by its campaign against the Assyrians, who were considered as an important adjunct of the British presence. The military began to enter the political scene and some of army officers, stimulated by nationalist idcas and influenced by the authoritarian regimes which were taking place outside the country, started to call for military rulc. The civillian politicians, sccking to lead the intelligentsia, responded with liberal and social democratic slogans and programs. In the confusion of these competing ideas and forces, military intervention in politics increased. 21

The authoritarian regime that excrted the most powerful influence on Iraqis, cspecially on the older gencration of nationalists, was that of Kemal Atatürk in Turkey. The modernist and progressive nature of the new Turkish Republic over the border had a high appealing effect among them, as it had clscwhere in the Islamic world. No other Middle Eastern leader has had

${ }^{20}$ Sluglett/Sluglett, Iraq since 1958, p. 15.

${ }^{21}$ F.O. 371/800/288. Hoare (Baghdad) to Simon, 28 August 1933. Also see Survey of International Affairs, 1934, London, 1936, pp. 122-134 and K. Husry, The Assyrian Affair of 1933', International Journal of Middle East Studies, Vol. 5, 1974, pp. 161-176. 
anything approaching Atatürk's charisma, reputation or political power. Indecd Alatürk's personality and his modernising reforms, which werc aimed at creating a strong state on Europcan lines, attracted much interest in Iraq. Many of the Ottoman-trained army officers could casily imagine themselves in the Turkish President's role. These have expressed admiration openly for Alatürk, scveral politicians, including Yasin al-Hashimi, bcing credited with personal desires to emulatc his part. It has been no secret that public opinion, its confidence shaken in the Council of Ministers and in Parliament, had lcancd increasingly towards Turkey and Alatürk as suitable models for Iraq. ${ }^{22}$

The army officers often discussed the existing situation in Iray and compared it unfavourably with the neighbouring government in Turkey. Just as the Kcmalist administration in Turkcy was climinating forcign control and carrying out reforms, so should the army officers in Iraq rulc their country in order to eleminate the last vestiges of forcign control, to create a stable political machinc, and, finally to liberate the sister Arab countrics which were still struggling towards frecdom and unity. Their model, as well as their inspiration, was indecd Kcmalist Turkey, because that country, they argued, had becn able to maintain its independence only through the reorganisation of its army. Iraq's lack of progress and governmental instability were contrasted with the spectacular achicvements of the new Turkish regime and the solidity of the Kemalist government. As a Moslem country with a background of similar traditions and problems, Turkey offered a more attainable example than Europcan regimes. Although Turkcy's radical sccularisation found few advocates among older Iraqis, the use of the state to encourage the development of industry, agriculture and education did have wide appeal. Above all, Kemal Atatürk's masterful handling of Parliament secmed, particularly to military, to sct an example worth following. 23

By the end of October 1936 the situation was considered to be ripe for the first of the many military coups which have since staken Iraq. General Bakr Sidqi, a graduate of the War College of lstanbul who served in command position in the Ottoman army throughout the First World War and who joined the newly-formed Iraqi army in 1921, scized power after staging a military coup. Sidqi had looked at the leader of his ncighbour, Turkey, and found it significant that he had arisen from humble army ranks to rule his country and carry out reforms. ${ }^{24}$

22P. Marr, The Modern History of Iraq, London, 1985, p. 70. Also Pierre Rondot. 'La Turquic et les Problèmes Mediterranćes', Politique Etrangère, Vol. 4 (5), 1939, p. 542. On Kemalist government and reforms see especially P. B. Kinross, Atatürk: The Rebirth of a Nation, London, 1964, pp. 337-397 and B. Lewis, The Emergence of Modern Turkey, London, 1961, pp. 473-483.

23 Ib id.

${ }^{24}$ M. Khadduri, Independent Iraq, London, 1951, pp. $78-81$. 
Hikmat Sulciman, an Otoman cducatcd lawyer who admired the achicvements of the Kemalist movement in Turkey, became the Prime Minister and Bakr Sidqi acceding to the post of the Chicl of Gencral Staff became the strong man and the real ruler of the country. Sulciman, Sidqi's personal friend, had helped to establish liaison between the young intelligentsia and the army. The former emerged as the hero of the revolution and it was entircly due to his efforts that the latter was won for the group of radical intellectuals. Sulciman, the younger brother of the pre-war Young Turk general Mahmut Şcvket Pasha, must have remembered his brother's great adventurous feat when he marched on Istanbul at the head of the revolutionary Ottoman Movement Army in July 1909, demanding the abdication of the monarch. With that memory in mind, Sulciman persuaded Sidqi to lcad a revolution in the Irayi army in order to force the existing cabinct to resign. 25

Of all the Iraqi politicians, Sulciman was best known for his courageous and adventurous spirit, for his frankness and straightforwardness. He became popular among the young men because he appeared to them as a progressive clder politician. He called himself a reformist on the lines of the Kemalist movement in Turkey. His whole social and cconomic background was based on his own understanding of the Kemalist government. In 1935, he had spent a few months in Turkey. He visited some of its industrial complexes and acquainted himself with the country's social and cconomic development. Sulciman had been trained in Istanbul and had always admired the Turks, but on this visit he was much more impressed as he was able to compare the development under the Kemalist administration with the Ottoman reign under the sultans. In December 1935, Sulciman returned to Iraq and was scen walking down the strects of Baghdad with a hat on his head - one noticeable sign of the cffect of his visit to Turkey. His admiration for the Turkish leader had further increased after his visit to Turkey, following which he wrote several articles advocating a thoroughgoing modernisation and sccularisation on Ankara's lincs. 26

Both Sidqi and Sulciman were under the spell of the Kcmalist principles and practices and both tried to take them as a model for Iraq. They were both ardently pro-Turkish and had almost the same outlook. One of Suleiman's first official acts was to announce that he would visit Ankara to cement Turkish-Iraqi friendship and to observe Turkish reforms for possible introduction into Iraq. He considered that the example provided by Atatürk was one to follow, that true advancement was impossible so long as religious fanaticism remained. The new leadership had the greatest respect for

25 Ibid., p. 75.

${ }^{26}$ Ibid. Also Marr, Modern History of Iraq, p. 69. 
the progress registered by Republican Turkey. The most concrete result of Sidqi's rule was the rapprochement with Turkey which was expressed by the signing, on 9 July 1937, of the Saadabad Pact. In comparison with Turkey, which was homogencous and frec of any forcign influence, Iraq under British supervision still had to content with great difficulty for internal cquilibrium in questions of minoritics, colonisation of interior and finances. The reformist plans of the new government remained largely unimplemented and Sidqi was assassinated by a group of dissident officers on 11 August 1937 in Mosul while on his way to attend military mancocuvres in Thrace, in response to an official invitation from the Turkish government. Sidqi's proTurkish policy clicitcd some praise in the British press, the year 1937 being one of gradual Anglo-Turkish rapprochement as a result of the worsening European situation. 27

It must be cmphasised, however, that from the point of vicw of historical parcllel it would be far more accurate to compare the Sidqi regime with the short-lived governments of the Committce of Union and Progress sct up by Western-influenced Turkish officer-intellectual groups in revolt against the monarchical rulc. Unlikc Atatürk, who established his political regime as a victorious Commander-in-Chicf and who had real control over his brethren officers as well as over the country as a whole, Sidqi was goaded into action by a scries of failures which Iraq had faced.

The military coup of October 29, 1936 proved to be a major turning point in Iraqi history. It made a critical breach in the constitution and paved the way for further army involvement in politics. The army had tested power and it gradually came to control political affairs. The coup was the first step toward the events of April 1941. The most important immediate effect of the coup was to remove the lcading figures of the previous government from Iraq. It made a clean, if temporary, swecp of the old ruling group that had governed the country since it was founded. Only one vetcran politician, Hikmat Sulciman, could find his way into the new government. 28

For the next four ycars, until the spring of 1941, governments were made and dismissed according to the wishes of the army officers, and six more military coups had taken place within this period. By this time, the military and civilian politicians had become divided broadly into two: those who were supporting Britain and its allies against the Axis powers and those who were not. Britain's most prominent supporters were the Regent Abd al Illah and Nuri al-Said, and its most outstanding opponents were Rashid Ali

27. Cabinet Office Papers, Public Record Office, London -henceforth referred to as 'C.A.B.'- 23/86. Cab 62 (36), 4 November 1936. And Bulletin of International Affairs, Vol. 14 (4), 1977, p. 21.

${ }^{28}$ M. Khadduri, The Coup d'Etat of 1936: A Study in Iraqi Politics', Middle East Journal, Vol. 2 (3), 1948, pp. 270-292. 
al-Ghailani and his circle, who enjoyed the support of a powerful faction of officers known as the 'Golden Square'. In April 1941, the then ruling group of colonels, the 'Golden Square', slithered into a war with Britain - caused essentially by their resentment of Britain's privileged position and expressed in their refusal to let Britain make full use of Iraq's territory and communications for the war effort. A bricf campaign by the British forces in May ended with the routing of the Iraqi army. After the defeat of the Rashid Ali movement, Iraq was secured to the Allied side by the co-operation of the Regent and an establishment of senior politicians, such as Jamil al-Midfai and Ali Jawdat, among whom Nuri al-Said predominated. 29

Apart from their other aspects, the 1936 and 1941 military coups could, in a sense, be vicwed also as rebellions by the younger or second line of ex-Sharifians, or by the post-1918 Sharifian recruits against the dominant, minister-furnishing ex-Sharifian elements: Brigadier Bakr Sidqi and Brigadier Abdul Latif Nuri, who staged the 1936 coup, and all four of the coloncls who were behind the 1941 military movement: Salah ud-Din as-Sabbagh, Kamil Shabib, Fahmi Said and Mahmud Salman were cx-Sharifians of the post1918 group. They all had attended the War College in Istanbul, fought on the Ottoman side in the war and joined Faisal's movement in Syria. 30

Following 1941, Nuri al-Said was the leading statesman of Iraq and the chicf representative of the Hashemite cstablishment, whether he was in or out office. Even when he did not serve as minister, he was not really out of power, for he cither inlluenced policy through a protégé or through the head of statc as a privy counscllor. In the post Sccond World War cra, Iraq's political forces were divided into two broad major groups: the ruling conscrvative group deriving its strength primarily from land-owning clements, more particularly the sheiks of the Middle Euphrates and the nationalist and socialist opposition relying, by and large, on support in the cities. The conservative group tended to rally around the person of Nuri alSaid, who emerged as time went on, not only as an undisputed leader of the status quo forces, but also as the 'strong man of Iraq'. He acted as the chicf supporter and scrvant of the Hashemite dynasty, bold spokesman for closer ties with Britain and the West. 31

Nuri al-Said succected in organising not only a devoled following among the traditional rank and file but also in subordinating to his leadership an impressive number of conservative elder statesmen. Such former Premiers

\footnotetext{
29 Ibid.

${ }^{30}$ Batatu, Old Social Classes, p. 337.

${ }^{31}$ Lenczowski, Middle East in World Affairs, pp. 252-253. For a full political biography of Nuri al-Said sec in particular Lord W. Birdwood, Nuri al-Said: $\Lambda$ Study in $\Lambda$ rab Leadership, London, 1959.
} 
as Jamil al-Midrai, Ali Jawdat, Tewlik as-Suwcidi and Arshad al-Umari, though they might have worked at cross-purposes under Icss skilful guidance, tended to co-operatc with cach other and with Nuri al-Said as a fairly harmonious tcam. Becalusc of this trusted team of associates, it was Nuri alSaid's government which by and large ruled the country in the 1950s irrespective of whether or not he headed the cabinct himself. He sought to maintain stable government through firm and frequently autocratic measures and attempted to modernise the country gradually by the use of rapidly increasing oil revenues. ${ }^{32}$

Nuri al-Said detcrmined the country's policy, which meant externally close collaboration with the West and internally a police statc, though in retrospect his rulc may look less repressive than it did then. He belicved in the necd for a firm alliance with Britain and loyally supported the Hashemite dynasty. He feared and hated communism and distrusted the Soviet Union. In Arab affairs, he was kcenly conscious of Iraq's age-old rivalry with Egypt. He favoured a Federation of the Fertile Crescent under Irayi leadership. Late in 1942, he submittcd a scheme along this line to Britain and the Arab statcs, but it met with strong Arab opposition, particularly Egyptian, and he did not pursue it. ${ }^{33}$

In domestic affairs, Nuri al-Said tricd to promotc administrative efficiency and cconomic planning. He was a conservative, even an autocrat, and did not belicve that parliamentary democracy was a suitable from of government for Iraq. During his last years Nuri al-Said was not in tune with the social and political forces swceping both the Arab world and Iray and secmed to have little understanding of them. ${ }^{34}$

The inability of the ruling stratum to grapple with the basic structural problems stemmed from the necessity of its situation, i.c. from its living links with the established social classes. The big landowners and wealthy merchants provided the core of his political support. Moreover, Nuri al-Said and the other principal ex-Sharifians had by this time become, economically, members of the established order. It should be mentioned that the outstanding Ottoman-trained officers had become part of the agricultural and commercial interests and less and less conscious and comprehending of the lower echelons of the people and the problems and difficultics of their daily lifc. ${ }^{35}$

${ }^{32}$ M. Khadduri, Independent Iraq (1932-1958), London, 1960, pp. 351 352.

${ }^{33}$ Ibid.

${ }^{34}$ A. Hourani, A History of the Arab Peoples, London, 1991, pp. 367. 368 .

${ }^{35}$ Batatu, Old Social Classes, pp. 351-352. 
One can correctly state that the most enthusiastic Icaders of the Iraqi national movement werc young men, born in the 1880s and the carly 1890 s, who had received military training in Istanbul and that they have played a central role in the conduct of the state affairs both under the British mandatory rulc and during the cra of independence up to the overthrow of the monarchy on July 14,1958 . The ideas behind Ottoman government were duly passed on to the Iraqi officials trained in the Ottoman tradition, which was founded, above all, on the bedrock of authoritarian paternalism. Although these ideas were modified in time, they persisted with remarkable tenacity among Iraq's ruling group right through the first half of the twenticth century. Even among those committed to Arab nationalist goals, Ottoman values and idcals remained strong. Although a large number of them later scrved in the Sharifian forces, their first and last love remaincd in the Ottoman army, which they remembered and respected for its battle discipline, physical toughness, the quality of its commanders and its raw and incomparable fighting ability. Methods and views of the military-burcaucratic clite had not changed since their Ottoman days. They were all true to the old tradition of the Turks. Four centuries of Ottoman customs had left their mark. The new gencration of Iracis, no matter how vociferously they might denounce the Young Turks, resembled nothing so much as an Arab version of the Young Turks themselves.

Lastly, it would be fair to indicate that the activitics of the Ottomantraincd army officers bore fruit in the cstablishment of national governments, but their narrow nationalist view and conservative outlook, when charged with ruling the people, would not allow the more enlightened and liberal young men who emerged after the Second World War to share the authority with them. This fundamental conflict between the elder politicians and the new gencration could be said to lay at the root of the bloody revolution which culminated in the killings of King Faisal II, the Regent Abd al Illah and Nuri al-Said -the three main pillars of the ancient regime- and conscquently led to the climination of the Ottoman-trained army officers from the political life of Iraq. 